\title{
Leucobacter iarius sp. nov., in the family Microbacteriaceae
}

Correspondence

Rüdiger Pukall

rpu@dsmz.de

\section{Vishal S. Somvanshi, ${ }^{1}$ Elke Lang, ${ }^{2}$ Peter Schumann, ${ }^{2}$ Rüdiger Pukall, ${ }^{2}$ R. M. Kroppenstedt, ${ }^{2}$ Sudershan Ganguly ${ }^{1}$ and Erko Stackebrandt ${ }^{2}$}

\author{
${ }^{1}$ Division of Nematology, Indian Agricultural Research Institute, New Delhi 110012, India \\ ${ }^{2} \mathrm{DSMZ}$ - German Collection of Microorganisms and Cell Cultures GmbH, Inhoffenstrasse 7b, \\ 38124 Braunschweig, Germany
}

Members of those genera of the family Microbacteriaceae that contain 2,4-diaminobutyric acid in their B-type crosslinked peptidoglycan (Schleifer \& Kandler, 1972) differ from each other mainly in menaquinone type, cell wall sugars, $\mathrm{G}+\mathrm{C}$ content of the DNA and physiochemical features (Morais et al., 2004). The genus Leucobacter was proposed to accommodate Gram-positive rods with a distinct peptidoglycan with an unusual amino acid, $\gamma$-aminobutyric acid, a high percentage of menaquinone 11 (MK-11) and moderate $16 \mathrm{~S}$ rRNA gene sequence similarities with other members of the family. Diagnostic sugars were absent from the cell wall of Leucobacter komagatae, the only species available at the time of the study (Takeuchi et al., 1996). In 2004, three new members, Leucobacter chromiireducens, Leucobacter aridicollis (Morais et al., 2004) and Leucobacter albus (Lin et al., 2004), and in 2006 two new members, Leucobacter alluvii and Leucobacter luti (Morais et al., 2006), were added to the genus on the basis of the aforementioned properties.

Members of the genus Leucobacter have been isolated from diverse environments, such as activated sludge from a treatment plant containing chromium-contaminated wastewater (L. chromiireducens, L. aridicollis and L. luti) (Morais

The GenBank/EMBL/DDBJ accession number for the 16S rRNA gene sequence of strain $40^{\top}$ is $A M 040493$. et al., 2004, 2006) and from soil in Thailand (L.albus) (Lin et al., 2004), while L. komagatae was isolated as a contaminant from an ampoule containing 'Pseudomonas riboflavina' (=Devosia riboflavina) (Takeuchi et al., 1996) and L. alluvii from sediment of the Alviela river, Portugal. Here we report the isolation and characterization of a novel Leucobacter species from the bacterial flora associated with the entomopathogenic nematode Steinernema thermophilum (Ganguly \& Singh, 2000), recovered from soil in India.

Strain $40^{\mathrm{T}}$ was one of the isolates found in the course of identifying bacteria from infective juveniles of the entomopathogenic nematode Steinernema thermophilum by using a procedure established by Akhurst (1980) with the modifications described by Somvanshi et al. (2006). The type strains of recognized Leucobacter species were obtained from the DSMZ and CRBIP, Paris. Cultural characteristics of strain $40^{\mathrm{T}}$ are indicated in the species description.

Genomic DNA was extracted using a DNeasy Tissue kit (Qiagen) following the manufacturer's instructions. The $16 \mathrm{~S}$ rRNA gene was amplified as described by Rainey et al. (1996). The PCR products were purified using a QIAquick PCR purification kit (Qiagen) and sequenced directly by using a CEQ Dye Terminator Cycle sequencing kit. The products were separated on a CEQ 8000 Genetic Analysis 
system. The 16S rRNA gene sequences were aligned with corresponding sequences from the database of DSMZ using the ae2 editor (Maidak et al., 1997). Evolutionary distances were calculated using the method of Jukes \& Cantor (1969). A phylogenetic tree based on distance analysis, reconstructed using the neighbour-joining algorithm (Saitou \& Nei, 1987), and bootstrap values were determined by analysing 1000 resamplings (Felsenstein, 1993).

The 16S rRNA gene sequence of strain $40^{\mathrm{T}}$ (1508 nt) showed 97.3-98.5\% similarity to those of type strains of recognized species of the genus Leucobacter, the closest relative being $L$. aridicollis (Fig. 1). However, these values were lower than those determined for certain strain pairs, such as L. albus and L. aridicollis $(98.9 \%), L$. albus and L. komagatae $(98.8 \%)$ and L. komagatae and L. aridicollis $(98.7 \%)$. As previous studies have confirmed DNA-DNA reassociation values of less than $70 \%$ for the latter two strain pairs with high 16S rRNA gene similarities [40\% (Lin et al., 2004) and $38 \%$ (Morais et al., 2004, 2006), respectively], we refrained from testing this parameter and consider strain $40^{\mathrm{T}}$ to represent a distinct genospecies (see also Stackebrandt \& Ebers, 2006).

Physiological and biochemical tests on strain $40^{\mathrm{T}}$ and the type strains of other Leucobacter species were performed at $28^{\circ} \mathrm{C}$ using API $50 \mathrm{CH}$ strips (bioMérieux), according to the manufacturer's instructions, with bioMérieux medium $\mathrm{E}$ [ $2 \mathrm{~g}$ ammonium sulphate, $0.5 \mathrm{~g}$ yeast extract, $1 \mathrm{~g}$ tryptone (bovine/porcine origin), $3.22 \mathrm{~g}$ disodium phosphate, $0.12 \mathrm{~g}$ monosodium phosphate, $10 \mathrm{ml}$ trace elements, $0.17 \mathrm{~g}$ phenol red, $1000 \mathrm{ml}$ demineralized water]. All tests were

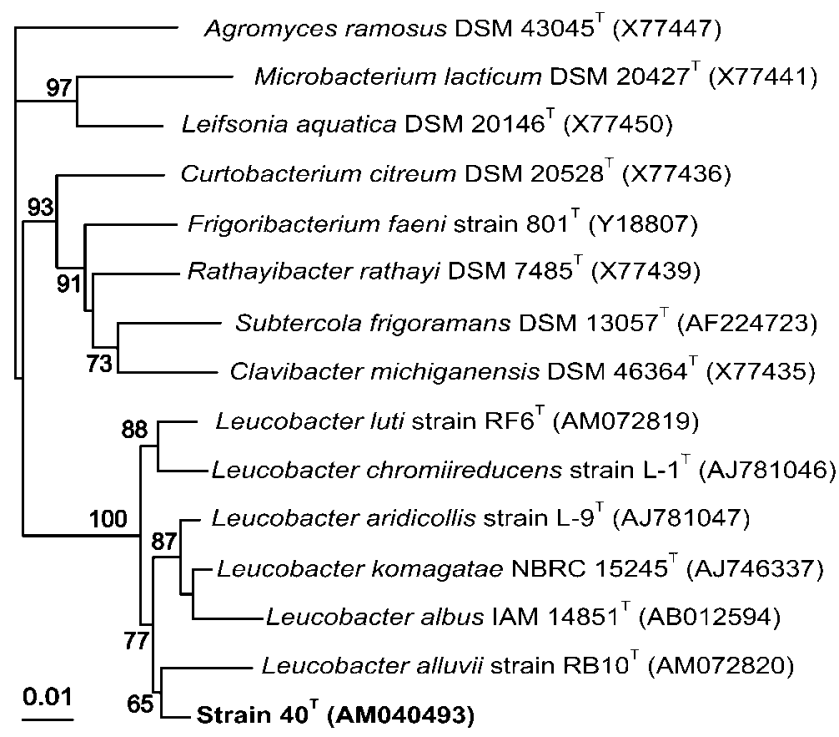

Fig. 1. 16S rRNA gene-based phylogenetic tree (Felsenstein, 1993) showing the position of strain $40^{\top}$ among Leucobacter species and some other members of the family Microbacteriaceae. Bar, $1 \%$ sequence divergence. Bootstrap percentages greater than $70 \%$, based on 1000 resamplings, are shown. inoculated with $24 \mathrm{~h}$-old cultures grown on trypticase soy agar. The reactions were scored up to 5 days, as indicated by Morais et al. (2004). Strain $40^{\mathrm{T}}$ was also characterized by using an API 20NE strip. Biolog GP plates (Oxoid) were incubated for $24 \mathrm{~h}$ before being read. Wells showing a photometric value above 20 or $30 \%$ of the highest value of an individual strain were scored as weak or positive, respectively. Conventional biochemical tests were performed according to standard methods (Smibert \& Krieg, 1994). Cultural characteristics such as colony size, shape and colour were determined after $24 \mathrm{~h}$ incubation at $28^{\circ} \mathrm{C}$ on CASO agar plates (Merck). The temperature range for growth was determined by incubating inoculated slant cultures (trypticase soy agar, $\mathrm{pH} 7.0$ ) at $4,25,30,37$ and $45^{\circ} \mathrm{C}$. Growth was also assessed in trypticase soy broth (Difco) at pH 5-9. $\mathrm{pH}$ values of the test medium of less than 7.5 were obtained by adding $\mathrm{HCl}$ and $\mathrm{pH}$ values greater than 7.5 by addition of sterilized sodium sesquicarbonate buffer $(1 \mathrm{M})$. The ability to grow in the presence of $\mathrm{NaCl}$ was determined using trypticase soy broth containing $\mathrm{NaCl}(5,7$ or $10 \%)$. Growth characteristics are given in the species description.

On the basis of the results of the physiological tests, it was concluded that strains of the genus Leucobacter react negatively towards most of the substrates provided on the API $50 \mathrm{CH}$ panel. There was no common substrate on the API $50 \mathrm{CH}$ test panels that was acidified by all members of the genus (Table 1). According to Morais et al. (2004), many

Table 1. Results of substrate acidification as determined using an API $50 \mathrm{CH}$ test panel with medium E, scored after 2 days

Strains: 1, strain $40^{\mathrm{T}}$ (Leucobacter iarius sp. nov.); 2, L. albus DSM $17379^{\mathrm{T}} ; 3$, L. chromiireducens DSM $17381^{\mathrm{T}} ; 4$, L. aridicollis DSM $17380^{\mathrm{T}}$; 5, L. komagatae DSM $8803^{\mathrm{T}}$; 6, L. luti CIP $108818^{\mathrm{T}}$; 7, L. alluvii CIP $108819^{\mathrm{T}}$. L. luti was weakly positive for production of acid from rhamnose. All strains were negative for all other substrates provided on the API $50 \mathrm{CH}$ test panels. +, Positive; - , negative; $\mathrm{W}$, weakly positive.

\begin{tabular}{|lccccccc|}
\hline Acidification reaction & $\mathbf{1}$ & $\mathbf{2}$ & $\mathbf{3}$ & $\mathbf{4}$ & $\mathbf{5}^{*}$ & $\mathbf{6}$ & $\mathbf{7}$ \\
\hline Glycerol & + & W & - & - & + & - & - \\
D-Arabinose & - & W & - & - & - & - & - \\
L-Arabinose & - & - & - & - & W & - & - \\
D-Adonitol & - & - & - & - & W & - & - \\
Ribose & + & + & - & - & + & + & - \\
Fructose & + & - & - & - & - & - & - \\
N-Acetylglucosamine & + & - & - & - & - & - & - \\
Trehalose & - & + & - & - & - & - & - \\
L-Fucose & - & + & - & - & - & - & - \\
5-Ketogluconate & W & - & - & - & - & - & - \\
Inositol & W & - & - & - & - & W & - \\
Salicin & W & - & - & - & - & - & - \\
\hline
\end{tabular}

${ }^{\star}$ Data from Morais et al. (2004). 
Table 2. Results of substrate utilization as determined by using a Biolog GP2 test panel, scored after $24 \mathrm{~h}$

Strains: 1, strain $40^{\mathrm{T}}$ (Leucobacter iarius sp. nov.); 2, L. albus DSM $17379^{\mathrm{T}}$; 3, L. chromiireducens DSM $17381^{\mathrm{T}}$; 4, L. aridicollis DSM $17380^{\mathrm{T}}$; 5, L. komagatae DSM $8803^{\mathrm{T}}$; 6, L. luti CIP $108818^{\mathrm{T}}$; 7, L. alluvii CIP $108819^{\mathrm{T}}$. All strains tested negative for all other substrates on the Biolog GP2 test plates. ++ , Very strong reaction ( $>70 \%$ of highest reading); + , strong reaction $(30-70 \%)$; W, $20-30 \%$; $-<20 \%$.

\begin{tabular}{|c|c|c|c|c|c|c|c|}
\hline Carbon source & 1 & 2 & 3 & 4 & 5 & 6 & 7 \\
\hline Dextrin & - & - & - & - & - & - & + \\
\hline Tween 40 & ++ & ++ & ++ & + & + & ++ & ++ \\
\hline Tween 80 & + & ++ & + & + & + & ++ & + \\
\hline Glucose & - & - & - & - & - & - & ++ \\
\hline$N$-Acetylglucosamine & + & - & - & - & - & - & - \\
\hline D-Fructose & ++ & - & - & - & - & - & + \\
\hline D-Psicose & $\mathrm{W}$ & - & - & - & - & - & W \\
\hline D-Ribose & + & ++ & - & + & + & - & - \\
\hline Xylitol & - & - & - & - & - & - & + \\
\hline D-Trehalose & - & + & - & - & - & - & - \\
\hline$\alpha$-Hydroxybutyric acid & - & - & - & - & - & - & - \\
\hline$\beta$-Hydroxybutyric acid & - & - & - & + & - & - & - \\
\hline $\begin{array}{l}p \text {-Hydroxyphenylacetic } \\
\text { acid }\end{array}$ & + & - & + & + & $\mathrm{W}$ & + & + \\
\hline $\begin{array}{l}\text { D-Lactic acid methyl } \\
\text { ester }\end{array}$ & - & - & - & - & - & - & w \\
\hline L-Lactic acid & - & - & - & - & - & - & + \\
\hline$\alpha$-Ketovaleric acid & - & + & - & $\mathrm{W}$ & - & - & - \\
\hline $\begin{array}{l}\text { Pyruvic acid methyl } \\
\text { ester }\end{array}$ & - & + & + & - & - & + & + \\
\hline Pyruvic acid & - & ++ & + & + & - & - & W \\
\hline $\begin{array}{l}N \text {-Acetyl-L-glutamic } \\
\text { acid }\end{array}$ & - & + & - & - & - & $\mathrm{W}$ & - \\
\hline L-Alaninamide & + & + & ++ & + & + & - & ++ \\
\hline L-Alanine & $\mathrm{W}$ & $\mathrm{W}$ & + & + & - & + & + \\
\hline L-Alanyl glycine & - & + & - & + & - & - & + \\
\hline L-Asparagine & - & + & - & + & - & - & - \\
\hline L-Glutamic acid & $\mathrm{W}$ & + & + & + & $\mathrm{W}$ & $\mathrm{W}$ & - \\
\hline $\begin{array}{l}\text { Glycyl-L-glutamic } \\
\text { acid }\end{array}$ & + & + & + & + & $\mathrm{W}$ & $\mathrm{W}$ & - \\
\hline L-Serine & $\mathrm{W}$ & + & - & + & - & - & - \\
\hline Glycerol & ++ & + & - & + & + & - & ++ \\
\hline Adenosine & + & $\mathrm{W}$ & $\mathrm{W}$ & ++ & - & - & + \\
\hline 2'-Deoxyadenosine & - & + & $\mathrm{W}$ & ++ & + & $\mathrm{W}$ & - \\
\hline Inosine & - & $\mathrm{W}$ & - & + & - & - & - \\
\hline Thymidine & ++ & ++ & $\mathrm{W}$ & ++ & - & - & + \\
\hline Uridine & + & + & + & + & - & - & - \\
\hline $\begin{array}{l}\text { Adenosine } \\
5^{\prime} \text {-monophosphate }\end{array}$ & $\mathrm{W}$ & - & - & ++ & - & - & - \\
\hline $\begin{array}{l}\text { Thymidine } \\
5^{\prime} \text {-monophosphate }\end{array}$ & + & + & - & ++ & - & - & - \\
\hline $\begin{array}{l}\text { Uridine } \\
5^{\prime} \text {-monophosphate }\end{array}$ & + & W & - & + & - & - & - \\
\hline Putrescine & ++ & ++ & ++ & ++ & ++ & ++ & ++ \\
\hline
\end{tabular}

tests were scored 'weak' for $L$. chromiireducens and $L$. aridicollis in the original description whereas, according to our results, they were negative for all the respective substrates even when read after 5 days. The Biolog GP test plates were more suitable for distinguishing Leucobacter strains (Table 2). These data reveal a clear preference of the strains for utilization of amino acids over carbohydrates. Strain $40^{\mathrm{T}}$ differed from the other strains in utilization of $\mathrm{N}$ acetylglucosamine and the weak acidification of 5-ketogluconate and salicin within the API $50 \mathrm{CH}$ substrate panels. In addition, a change of the indicator dye was observed for fructose (Table 1). The reactions of some strains towards certain substrates differed between the Biolog and API substrate panels (Tables 1 and 2).

Cultures for use for determination of the fatty acid composition were grown on trypticase soy broth agar for $24 \mathrm{~h}$ at $28^{\circ} \mathrm{C}$. Processing and analysis of fatty acids as methyl esters were done using the protocol of the MIDI Sherlock Microbial Identification System (MIDI, 1999).

Cellular fatty acid analysis was carried out for all the type strains except L. komagatae IAM $1093^{\mathrm{T}}$, L. luti CIP $108818^{\mathrm{T}}$ and L. alluvii CIP $108819^{\mathrm{T}}$, for which data were taken from Takeuchi et al. (1996) and Morais et al. (2006) (Table 3). The major fatty acids of strain $40^{\mathrm{T}}$ were anteiso- $\mathrm{C}_{15: 0}$ $(41.9 \%)$, anteiso- $\mathrm{C}_{17: 0}(33.6 \%)$ and iso- $\mathrm{C}_{16: 0}(15.5 \%)$. These results are in accord with the fatty acid compositions of other members of the genus, confirming the affiliation of strain $40^{\mathrm{T}}$ with the genus.

Purified cell wall preparations were obtained by using the method of Schleifer \& Kandler (1972). Amino acids and peptides in cell wall hydrolysates were analysed by twodimensional ascending thin layer chromatography on cellulose plates using previously described systems (Schleifer \& Kandler, 1972). The N-terminal amino acid of the interpeptide bridge was determined by dinitrophenylation as

Table 3. Major fatty acid compositions (\%) of Leucobacter species

Strains: 1, strain $40^{\mathrm{T}}$ (Leucobacter iarius sp. nov.); 2, L. albus DSM $17379^{\mathrm{T}} ; 3$, L. chromiireducens DSM $17381^{\mathrm{T}} ; 4$, L. aridicollis DSM $17380^{\mathrm{T}}$; 5, L. komagatae IAM $1093^{\mathrm{T}}$; 6, L. luti CIP $108818^{\mathrm{T}}$; 7, L. alluvii CIP $108819^{\mathrm{T}}$. The fatty acid content differs slightly from that reported by Morais et al. (2004). ND, No data available.

\begin{tabular}{|c|c|c|c|c|c|c|c|}
\hline Fatty acid & 1 & 2 & 3 & 4 & $5^{*}$ & $6 \dagger$ & $7 \dagger$ \\
\hline anteiso- $\mathrm{C}_{15: 0}$ & 41.86 & 54.20 & 55.28 & 50.86 & 65 & 61 & 51 \\
\hline anteiso- $\mathrm{C}_{17: 0}$ & 33.58 & 19.08 & 23.73 & 26.27 & 22 & 14 & 25 \\
\hline iso- $\mathrm{C}_{16: 0}$ & 15.50 & 17.04 & 11.53 & 11.37 & 13 & 12 & 9 \\
\hline iso- $\mathrm{C}_{15: 0}$ & 2.83 & 3.49 & 0.91 & 3.43 & - & ND & ND \\
\hline $\mathrm{C}_{16: 0}$ & 4.16 & 4.06 & 5.80 & 6.15 & - & 7 & 12 \\
\hline
\end{tabular}

^From Takeuchi et al. (1996).

$\dagger$ From Morais et al. (2006). 
described by Schleifer (1985). Strain $40^{\mathrm{T}}$ possessed glutamic acid (1.0), L-diaminobutyric acid (0.5), alanine (1.5), glycine (0.9) and threonine (0.7), a composition that confirmed the presence of a B-type cross-linked peptidoglycan. As revealed by denitrophenylation, alanine was the N-terminal amino acid. The dipeptide Gly-Glu was detected after partial hydrolysis. 4-Aminobutyric acid, as detected in some other Leucobacter strains (L. komagatae, L. albus), was not observed. The $\mathrm{N}$-terminal alanine, the presence of threonine and the Gly-Glu dipeptide corresponds to the information reported for L. chromiireducens, L. luti and L. alluvii (Morais et al., 2006). Lipoquinone and polar lipid analyses were done by using previously described methods (Groth et al., 1996). The dominant menaquinone was MK-11, consistent with the results obtained with the type strains of other Leucobacter species. MK-10 and MK-9 were present in minor amounts, while MK-12 occurred in trace amounts only. The polar lipids were phosphatidylglycerol and diphosphoglycerol. Several unidentified components occurred, i.e. a phospholipid, a glycolipid and an aminophospholipid.

In conclusion, based upon the phylogenetic and chemotaxonomic evidence, strain $40^{\mathrm{T}}$ represents a novel member of the genus Leucobacter, family Microbacteriaceae, for which the name Leucobacter iarius sp. nov. is proposed.

\section{Description of Leucobacter iarius sp. nov.}

Leucobacter iarius [i.a'ri.us. N.L. masc. adj. iarius (arbitrary name) formed from the acronym IARI (Indian Agricultural Research Institute, New Delhi, India) to commemorate its centenary year].

Cells are Gram-positive, straight, non-motile rods $(1.66-2.91 \times 0.37-0.49 \mu \mathrm{m})$. Neither mycelium nor spores are detected. Colonies are round, $0.4-1 \mathrm{~mm}$ in diameter with smooth edges, low-convex, opaque, whitish in colour, finely granular and odourless. Optimum temperature for growth is $30^{\circ} \mathrm{C}$; growth does not occur at temperatures higher than $37^{\circ} \mathrm{C}$ or at $4{ }^{\circ} \mathrm{C}$. Growth occurs at pH 5.0-9.0. Growth is reduced in the presence of $5-7 \% \mathrm{NaCl}$; no growth occurs with $10 \% \mathrm{NaCl}$. Urease-negative, nitrate is not reduced, D-glucose is not fermented, and aesculin and PNPG ( $\beta$-galactosidase) are positive on API $20 \mathrm{NE}$ strips. Gelatinase-negative. Utilizes $N$-acetylglucosamine and weakly utilizes 5-ketogluconate, inositol and salicin. Additional biochemical and physiological characteristics are given in Tables 1 and 2. MK-11 is the major menaquinone; MK-10 and MK-9 are present in minor amounts while MK-12 occurs in trace amounts only. Polar lipids are phosphatidylglycerol and diphosphoglycerol. Several unidentified components occur, i.e. a phospholipid, a glycolipid and an aminophospholipid. Cross-linkage of peptidoglycan is of the B-type; cell wall amino acids are L-diaminobutyric acid, alanine, glycine, threonine and glutamic acid. 4-Aminobutyric acid is absent. Major fatty acids are anteiso- $\mathrm{C}_{15: 0}$, anteiso- $\mathrm{C}_{17: 0}$ and iso- $\mathrm{C}_{16: 0}$; iso$\mathrm{C}_{15: 0}$ and $\mathrm{C}_{16: 0}$ are present in minor amounts.
The type strain is strain $40^{\mathrm{T}}\left(=\mathrm{DSM} 17402^{\mathrm{T}}=\mathrm{CIP} 108831^{\mathrm{T}}\right)$, which was isolated from crushed infective juveniles of Steinernema thermophilum collected from soil of the Indian Agricultural Research Institute, New Delhi, India.

\section{Acknowledgements}

Financial support for V.S.S. from the German Academic Exchange Service (Deutscher Akademischer Austausch Dienst - DAAD) for this project is greatly acknowledged. A Senior Research Fellowship to V.S.S. from the IARI is also acknowledged. We thank Ina Kramer, Jolantha Swiderski, Ulrike Steiner, Jennifer Gregor, Markus Kopitz, Evelyne Brambilla and Anja Frühling for excellent technical assistance and Hans Trüper for his advice on nomenclatural matters.

\section{References}

Akhurst, R. J. (1980). Morphological and functional dimorphism in Xenorhabdus spp., bacteria symbiotically associated with the insect pathogenic nematodes Neoaplectana and Heterorhabditis. J Gen Microbiol 121, 303-309.

Felsenstein, J. (1993). PHYLIP (phylogeny inference package), version 3.5.1. Department of Genome Sciences, University of Washington, Seattle, USA.

Ganguly, S. \& Singh, L. K. (2000). Steinernema thermophilum sp. n. (Rhabditida: Steinernematidae) from India. Int J Nematol 10, 183-191.

Groth, I., Schumann, P., Weiss, N., Martin, K. \& Rainey, F. A. (1996). Agrococcus jenensis gen. nov., sp. nov., a new genus of actinomycetes with diaminobutyric acid in the cell wall. Int J Syst Bacteriol 46, 234-239.

Jukes, T. H. \& Cantor, C. R. (1969). Evolution of protein molecules. In Mammalian Protein Metabolism, pp. 21-132. Edited by H. N. Munro. New York: Academic Press.

Lin, Y.-C., Uemori, K., de Briel, D. A., Arunpairojana, V. \& Yokota, A. (2004). Zimmermannella helvola gen. nov., sp. nov., Zimmermannella alba sp. nov., Zimmermannella bifida sp. nov., Zimmermannella faecalis sp. nov. and Leucobacter albus sp. nov., novel members of the family Microbacteriaceae. Int J Syst Evol Microbiol 54, 1669-1676.

Maidak, B. L., Olsen, G. J., Larsen, N., Overbeek, R., McCaughey, M. J. \& Woese, C. R. (1997). The RDP (Ribosomal Database Project). Nucleic Acids Res 25, 109-111.

MIDI (1999). Sherlock Microbial Identification System Operating Manual, version 3.0. Newark, DE: MIDI.

Morais, P. V., Francisco, R., Branco, R., Chung, A. P. \& da Costa, M. S. (2004). Leucobacter chromiireducens sp. nov., and Leucobacter aridicollis sp. nov., two new species isolated from a chromium contaminated environment. Syst Appl Microbiol 27, 646-652.

Morais, P. V., Paulo, C., Francisco, R., Branco, R., Chung, A. P. \& da Costa, M. S. (2006). Leucobacter luti sp. nov., and Leucobacter alluvii sp. nov., two new species of the genus Leucobacter isolated under chromium stress. Syst Appl Microbiol 29, 414-421.

Rainey, F. A., Ward-Rainey, N., Kroppenstedt, R. M. \& Stackebrandt, E. (1996). The genus Nocardiopsis represents a phylogenetically coherent taxon and distinct actinomycete lineage; proposal of Nocardiopsaceae fam. nov. Int J Syst Bacteriol 46, 1088-1092.

Saitou, N. \& Nei, M. (1987). The neighbor-joining method: a new method for reconstructing phylogenetic trees. Mol Biol Evol 4, 406-425.

Schleifer, K. H. (1985). Analysis of the chemical composition and primary structure of murein. Methods Microbiol 18, 123-156. 
Schleifer, K. H. \& Kandler, O. (1972). Peptidoglycan types of bacterial cell walls and their taxonomic implications. Bacteriol Rev 36, 407-477.

Smibert, R. M. \& Krieg, N. R. (1994). Phenotypic characterization. In Methods for General and Molecular Bacteriology, pp. 607-654. Edited by P. Gerhardt, R. G. E. Murray, W. A. Wood \& N. R. Krieg. Washington, DC: American Society for Microbiology.

Somvanshi, V. S., Lang, E., Sträubler, B., Spröer, C., Schumann, P., Ganguly, S., Saxena, A. K. \& Stackebrandt, E. (2006). Providencia vermicola sp. nov., isolated from infective juveniles of the entomopathogenic nematode Steinernema thermophilum. Int J Syst Evol Microbiol 56, 629-633.

Stackebrandt, E. \& Ebers, J. (2006). Taxonomic parameters revisited: tarnished gold standards. Microbiology Today 33, 152-155.

Takeuchi, M., Weiss, N., Schumann, P. \& Yokota, A. (1996). Leucobacter komagatae gen. nov., sp. nov., a new aerobic Grampositive, nonsporulating rod with 2,4-diaminobutyric acid in the cell wall. Int J Syst Bacteriol 46, 967-971. 